\title{
Vitamin D can prevent COVID-19 infection-induced multiple organ damage
}

\author{
Hatice Aygun ${ }^{1}$ (D) \\ Received: 6 April 2020 / Accepted: 17 May 2020 / Published online: 25 May 2020 \\ (C) Springer-Verlag GmbH Germany, part of Springer Nature 2020
}

\begin{abstract}
Vitamin D is an immunomodulator hormone with an anti-inflammatory and antimicrobial effect with a high safety profile. A lot of COVID-19 infected patients develop acute respiratory distress syndrome (ARDS), which may lead to multiple organ damage. These symptoms are associated with a cytokine storm syndrome. The aim of this letter is to note the 5 crucial points that vitamin D could have protective and therapeutic effects against COVID-19. For that reason, COVID-19 infection-induced multiple organ damage might be prevented by vitamin $\mathrm{D}$.
\end{abstract}

Keywords Vitamin D · Covid-19 · Cytokine storm · Multiple organ damage

To the Editor,

I am writing this letter with an aim to note that vitamin $\mathrm{D}$ could have protective and therapeutic effects against COVID19.

Coronavirus disease 2019 (COVID-19) continues to spread very quickly and become fatal, since there is no effective treatment yet. For this reason, many countries resort to harsh quarantine precautions in order to curb the spread and prevent deaths.

It has been known that angiotensin-converting enzyme 2 (ACE2) is the main host cell receptor of COVID-19. ACE2 is expressed in type II alveolar cells of the lungs, absorptive enterocytes from the ileum and colon, esophagus upper and stratified epithelial, kidney proximal tubule cells, myocardial cells, bladder urothelial cells, and epithelial cells of the oral mucosa (Zou et al. 2020; Xu et al. 2020). The high expression of ACE2 could be a potential risk factor for infection routes of COVID-19. As a result of COVID-19 infection, many patients develop acute respiratory distress syndrome (ARDS), which may lead to multiple organ damage. These symptoms are associated with a cytokine storm syndrome, which might cause triggered T helper1 (Th1) cell responses. Many studies suggested that high concentrations of interleukin (IL)-1, IL-1B, IL-2, IL-6, IL-7, IL-8, IL-10, IL-12, IL-13, IL-17, granulocyte

Hatice Aygun

hatice_5aygun@hotmail.com; hatice.aygun@gop.edu.tr

1 Department of Physiology, Faculty of Medicine, Tokat Gaziosmanpasa University, 60030 Tokat, Turkey colony-stimulating factor (GCSF), interferon- $\gamma$ inducible protein 10 (IP-10), macrophage inflammatory protein 1- $\alpha$ (MIP$1 \alpha$ ), tumor necrosis factor- $\alpha$ (TNF- $\alpha$ ), monocyte chemoattractant protein 1 (MCP-1), and IFN- $\gamma$ could be found in COVID-19 infected patients (Conti et al. 2020; Chen et al. 2020a; Liu et al. 2020; Huang et al. 2020).

Vitamin D has been known to play a critical role in the immune system. Vitamin D receptor has been expressed in multiple organs and tissues including the heart, lungs, kidneys, liver, nervous system, intestine, bone, parathyroid gland, cardiovascular system, and myocardium (Prufer et al. 1999). Vitamin D (Fig. 1) could prevent multiple organ damage caused by COVID in the following five ways:

1. Vitamin D decreases the production of Th1 cells (Cantorna and Mahon 2005; Schleithoff et al. 2006; Ardizzone et al. 2009). Thus, it can suppress the progression of inflammation through reducing the generation of inflammatory cytokines such as IL-6, IL-8, IL-12, and IL17 (Chastre and Fagon 2002; Society et al. 2005; Palmer et al. 2011). Vitamin $D$ also decreases the generation of $\mathrm{TNF} \alpha$ and nuclear factor- $\mathrm{kB}$ (NFkB) (Peterson and Heffernan 2008; Talmor et al. 2008). Moreover, $1,25(\mathrm{OH}) 2 \mathrm{D}$, biological active form of vitamin $\mathrm{D}$, directly inhibits gamma interferon (IFN- $\gamma$ ) and IL-2 (Provvedini et al. 1983; Tsoukas et al. 1984). Vitamin D can reduce cytokine storm syndrome in patients with severe COVID-19 infection and thus prevent multiple organ damage. 


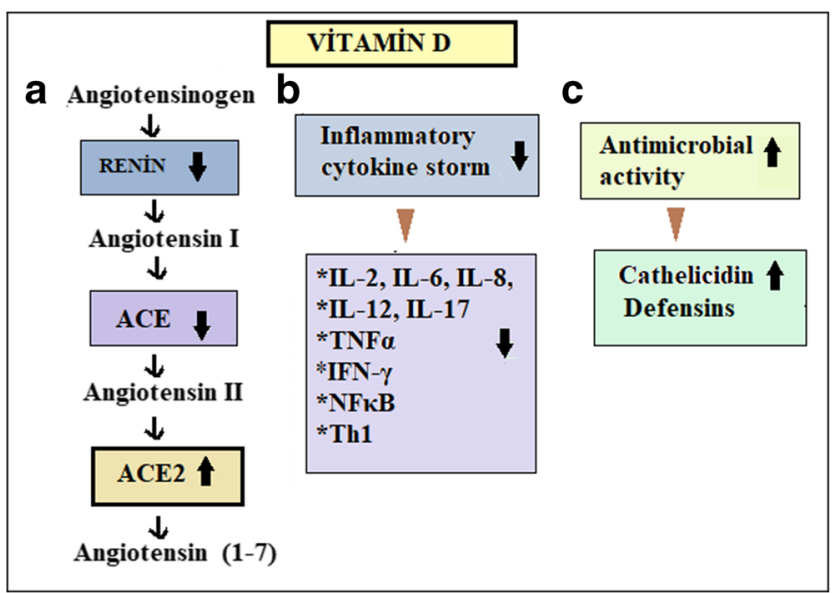

Fig. 1 a Vitamin D might prevent the development of ARDS, hypertension, and cardiovascular system disorders by reducing the level of renin, ACE, and angiotensin II and increasing the level of ACE2. b It can prevent the development of oxidative stress and organ damage by reducing inflammatory cytokines in many tissues. c Vitamin D may enhance antimicrobial activity by increasing defensins and cathelicidins peptides level. This could be effective against the COVID-19 infection

2. It was demonstrated that during viral infection, inactive vitamin $\mathrm{D}$ form can be converted to active form by the alveolar epithelial cells, and expression of the host defense gene cathelicidin increases (Hansdottir et al. 2008). Cathelicidins were shown to have a protective effect against lung damage due to hyperoxia (Jiang et al. 2020). Vitamin D could reduce the risk of COVID-19 infection by inducing the production of cathelicidin and defensins, which reduce the survival and replication of viruses.

3. In human with primary and secondary kidney disease and in mice with diabetes, increased ACE2 expression was demonstrated (Ye et al. 2004; Lely et al. 2004). Vitamin $\mathrm{D}$ treatment was shown to inhibit ACE2 expression in the kidney (Ali et al. 2018). 1,25-(OH)2D3 exhibited renoprotective effect by decreasing ACE1 and ACE1/ ACE2 ratio in streptozotocin-induced diabetic nephropatic rats (Lin et al. 2016). In other words, vitamin $\mathrm{D}$ treatment can suppress ACE2 expression in kidney tubule cells, thereby preventing COVID-19 entry into the cell in diabetic patients and protecting the kidney.

4. Angiotensin II (Ang II) is a natural peptide hormone in the renin-angiotensin-aldosterone system. It is best known for increasing the blood pressure through stimulating aldosterone and its systemic vasoconstriction ( $\mathrm{Li}$ et al. 2004). ACE2 directly catalyzes Ang II, thereby lowering its levels. COVID-19 infection may downregulate ACE2, which in turn could lead to excessive accumulation of Ang II. High levels of Ang II may cause ARDS, myocarditis, or cardiac injury (Hanff et al. 2020). Renin, on the other hand, is a proteolytic enzyme and a positive regulator of Ang II. Vitamin D is a potent inhibitor of renin ( $\mathrm{Li}$ et al. 2004). A study reported that vitamin D receptorlacking mice had elevated levels of renin and Ang II (Li et al. 2004). Indeed, vitamin D supplement was shown to prevent Ang II accumulation and to decrease proinflammatory activity of Ang II by suppressing the release of renin in patients infected with COVID, thus reducing the risk of ARDS, myocarditis, or cardiac injury (Hanff et al. 2020).

5. Epidemiology studies reported that mortality and severity of COVID-19 virus infection are strongly correlated with older people and male. It is known that especially in children, the risk of developing COVID-19 infection is lower and symptoms are less severe. A recent study examined the relationship between ACE2 expression in the lungs, and age 3-month-old mice significantly increased ACE2 expression when compared with 24-month-old mice (Booeshaghi and Pachter 2020). It has been shown that ACE2 expression decreases dramatically in male and female rats, and this decrease is also higher in female rats compared with male rats (Xudong et al. 2006). ACE2 expression is generally higher in females than in males and tends to reduce with age (Chen et al. 2020b). Children have higher ACE expression than adults (Beneteau-Burnat et al. 1990). The high incidence of COVID-19 infection in the older people and men may be associated with low ACE2 expression.

Severe acute respiratory syndrome coronavirus (SARSCoV) and acid aspiration-induced ARDS mouse model-mediated ACE2 downregulation cause severity of the lung failure (Kuba et al. 2006). In human coronavirus-NL63, downregulation of the ACE2 protein was observed (Dijkman et al. 2012). Similarly, in COVID-19 infection, the virus binds to ACE2 receptors, following downregulation of ACE2 and cannot perform its physiological function. A decrease in ACE2 expression might be a greater risk of ARDS, acute lung inflammation, cardiovascular diseases, hypertension, heart failure, cardiac fibrosis, and chronic kidney disease (Kuba et al. 2006; Sodhi et al. 2018; Tikellis and Thomas 2012).

Vitamin D deficiency is an important risk factor in ARDS as well as in many diseases. A single high-dose preoperative treatment with oral vitamin D was reported to prevent ARDS by reducing postoperative pulmonary vascular permeability index (Parekh et al. 2018). A study showed that vitamin D exhibits direct protective effect on alveolar epithelium, and decreased the death of the type 2 alveolar epithelial cells in lipopolysaccharide-induced ARDS mouse model; also, supplementation of vitamin D before the oesophagectomy prevents ARDS by reducing alveolar capillary damage, in clinical setting (Dancer et al. 2015). Another study demonstrated that vitamin $\mathrm{D}$ treatment was shown to have protective effect on the lungs by inhibiting renin, ACE, and Ang II level, and increased ACE2 level expression in acute lung injury model 
in animal (Xu et al. 2017). Calcitriol (1,25-dihydroxyvitamin D3) may enhance the expression of ACE2 by pronouncedly impact on ACE2/Ang(1-7)/MasR pathway (Cui et al. 2019).

Thus, vitamin $\mathrm{D}$ deficiency may play a role in increasing the risk of developing COVID-19 infection. Recently, several studies supporting this hypothesis have been published. A study reported that northern latitudes are associated with higher hospitalization rate and mortality rate for COVID-19 worldwide, because vitamin D deficiency is more prevalent in people who live in Northern countries (Panarese and Shahini 2020). There are negative correlations between mean levels of vitamin $\mathrm{D}$ in different countries and the number of COVID-19 cases (Ilie et al. 2020). On the other hand, in the body, a decrease in serum vitamin D level may worsen the clinical results of patients with COVID-19 and an increase in serum vitamin $\mathrm{D}$ level may improve clinical outcomes in those patients (Alipio 2020).

Vitamin D may protect against symptoms of the COVID19 infection, especially by increasing the level of ACE2 in the lungs. ACE2, as the key SARS receptor, does play a protective role in the cardiovascular diseases and SARS-mediated ARDS (Imai et al. 2007; Kuba et al. 2013). ACE2 protein treatment inhibited the spreading of SARS and also protect patients with SARS infection from developing lung failure (Kuba et al. 2006). Moreover, a single dose of recombinant human ACE2 treatment prevents pulmonary arterial hypertension both in clinical and preclinical study (Hemnes et al. 2018). A new study showed that human recombinant soluble ACE2 treatment may significantly suppressed early stages of SARS-CoV-2 infections (Monteil et al. 2020)

Consequently, vitamin D treatment may decrease the risk of incidence of the COVID-19 infection by increasing the ACE2 level, as well as decrease the mortality and severity of patients with COVID-19. For that reason, in the new treatment strategies, making plans to increase ACE2 might be successful to fight against the COVID-19 infection.

Yours sincerely.

Author's contributions HA: research concept, design, preparation, and revisions of the article. All data were generated in-house and that no paper mill was used.

\section{Compliance with ethical standards}

Conflict of interest The author declares that she has no conflict of interest.

\section{References}

Ali RM, Al-Shorbagy MY, Helmy MW, El-Abhar HS (2018) Role of Wnt $4 / \beta$-catenin, Ang II/TGF $\beta$, ACE2, NF-kB, and IL-18 in attenuating renal ischemia/reperfusion-induced injury in rats treated with Vit D and pioglitazone. Eur J Pharmacol 831:68-76

Alipio M (2020). Vitamin D supplementation could possibly improve clinical outcomes of patients infected with Coronavirus-2019 (COVID-2019). Available at SSRN 3571484

Ardizzone S, Cassinotti A, Trabattoni D, Manzionna G, Rainone V, Bevilacqua M, Massari A, Manes G, Maconi G, Clerici M, Porro GB (2009) Immunomodulatory effects of 1,25-dihydroxyvitamin D3 on TH1/TH2 cytokines in inflammatory bowel disease: an in vitro study. Int J Immunopathol Pharmacol 22:63-71

Beneteau-Burnat B, Baudin B, Morgant G, Baumann FC, Giboudeau J (1990) Serum angiotensin-converting enzyme in healthy and sarcoidotic children: comparison with the reference interval for adults. Clin Chem 36(2):344-346

Booeshaghi A, Pachter L (2020) Decrease in ACE2 mRNA expression in aged mouse lung. (Unpublished) https://resolver.caltech.edu/ CaltechAUTHORS:20200406-101324270. https://doi.org/10.1101/ 2020.04.02.021451

Cantorna MT, Mahon BD (2005) D-hormone and the immune system. J Rheumatol Suppl 76:11-20

Chastre J, Fagon JY (2002) Ventilator-associated pneumonia. Am J Respir Crit Care Med 165(7):867-903

Chen N, Zhou M, Dong X, Qu J, Gong F, Han Y, Qiu Y, Wang J, Liu Y, Wei Y, Xia J', Yu T, Zhang X, Zhang L (2020a) Epidemiological and clinical characteristics of 99 cases of 2019 novel coronavirus pneumonia in Wuhan, China: a descriptive study. Lancet 395(10223):507-513

Chen J, Jiang Q, Xia X, et al (2020b) Individual variation of the SARS$\mathrm{CoV} 2$ receptor ACE2 gene expression and regulation. Preprints, 2020030191

Conti P, Ronconi G, Caraffa A, Gallenga CE, et al (2020) Induction of pro-inflammatory cytokines (IL-1 and IL-6) and lung inflammation by Coronavirus-19 (COVI-19 or SARS-CoV-2): anti-inflammatory strategies, J Biol Regul Homeost Agents 34. https://doi.org/10. 23812/CONTI-E.

Cui C, Xu P, Li G et al (2019) Vitamin D receptor activation regulates microglia polarization and oxidative stress in spontaneously hypertensive rats and angiotensin II-exposed microglial cells: role of renin-angiotensin system. Redox Biol 26:101295. https://doi.org/ 10.1016/j.redox.2019.101295

Dancer RC, Parekh D, Lax S et al (2015) Vitamin D deficiency contributes directly to the acute respiratory distress syndrome (ARDS). Thorax 70:617-624

Dijkman R, Jebbink MF, Deijs M, Milewska A, Pyrc K, Buelow E, van der Bijl A, van der Hoek L (2012) Replication-dependent downregulation of cellular angiotensin-converting enzyme 2 protein expression by human coronavirus NL63. J General Virol 93(9):1924-1929

Hanff TC, Harhay MO, Brown TS, Cohen JB, Mohareb AM (2020) Is there an association between COVID-19 mortality and the reninangio-tensin system-a call for epidemiologic investigations. Clin Infect Dis ciaa329. https://doi.org/10.1093/cid/ciaa329

Hansdottir S, Monick MM, Hinde SL, Lovan N, Look DC, Hunninghake GW (2008) Respiratory epithelial cells convert inactive vitamin D to its active form: potential effects on host defense. J Immunol 181: 7090-7099

Hemnes AR, Rathinasabapathy A, Austin EA, Brittain EL, Carrier EJ, Chen X, Fessel JP, Fike CD, Fong P, Fortune N, Gerszten RE, Johnson JA, Kaplowitz M, Newman JH, Piana R, Pugh ME, Rice TW, Robbins IM, Wheeler L, Yu C, Loyd JE, West J (2018) A potential therapeutic role for angiotensin converting enzyme 2 in human pulmonary arterial hypertension. Eur Respir J 51:1702638. https://doi.org/10.1183/13993003.02638-2017

Huang C, Wang Y, Li X, Ren L, Zhao J, Hu Y, Zhang L, Fan G, Xu J, Gu X, Cheng Z, Yu T, Xia J, Wei Y, Wu W, Xie X, Yin W, Li H, Liu M, Xiao Y, Gao H, Guo L, Xie J, Wang G, Jiang R, Gao Z, Jin Q, Wang J, Cao B (2020) Clinical features of patients infected with 
2019 novel coronavirus in Wuhan, China. Lancet 395(10223):497506

Ilie PC, Stefanescu S, Smith L (2020) The role of vitamin D in the prevention of coronavirus disease 2019 infection and mortality. Aging Clin Exp Res. https://doi.org/10.1007/s40520-020-01570-8

Imai Y, Kuba K, Penninger JM (2007) Angiotensin-converting enzyme 2 in acute respiratory distress syndrome. Cell Mol Life Sci 64(15): 2006-2012

Jiang JS, Chou HC, Chen CM (2020) Cathelicidin attenuates hyperoxiainduced lung injury by inhibiting oxidative stress in newborn rats. Free Rad Biol Med 150:23-29

Kuba K, Imai Y, Rao S, Jiang C, Penninger JM (2006) Lessons from SARS: control of acute lung failure by the SARS receptor ACE2. J Mol Med 84(10):814-820

Kuba K, Imai Y, Penninger JM (2013) Multiple functions of angiotensinconverting enzyme 2 and its relevance in cardiovascular diseases. Circul J 77(2):301-308

Lely AT, Hamming I, van Goor H, Navis GJ (2004) Renal ACE2 expression in human kidney disease. J Pathol 204:587-593

Li YC, Qiao G, Uskokovic M, Xiang W, Zheng W, Kong J (2004) Vitamin D: a negative endocrine regulator of the reninangiotensin system and blood pressure. J Steroid Biochem Mol Biol 89:387-392

Lin M, Gao P, Zhao T, He L, Li M, Li Y, Shui H, Wu X (2016) Calcitriol regulates angiotensin-converting enzyme and angiotensin converting-enzyme 2 in diabetic kidney disease. Mol Biol Rep 43(5):397-406

Liu Y, Zhang C, Huang F, Yang Y, Wang F, Yuan J, et al (2020) 2019novel coronavirus (2019-nCoV) infections trigger an exaggerated cytokine response aggravating lung injury. http://www.chinaxiv. org/abs/202002.00018

Monteil V, Kwon H, Prado P, Hagelkrüys A, Wimmer RA, Stahl M, Leopoldi A, Garreta E, Hurtado del Pozo C, Prosper F, Romero JP, Wirnsberger G, Zhang H, Slutsky AS, Conder R, Montserrat N, Mirazimi A, Penninger JM (2020) Inhibition of SARS-CoV-2 infections in engineered human tissues using clinical-grade soluble human ACE2. Cell S0092-8674(20):30399-30398. https://doi.org/ 10.1016/j.cell.2020.04.004

Palmer MT, Lee YK, Maynard CL, Oliver JR, Bikle DD, Jetten AM, Weaver CT (2011) Lineage-specific effects of 1,25dihydroxyvitamin $\mathrm{d}(3)$ on the development of effector cd4 t cells. J Biol Chem 286:997-1004

Panarese A, Shahini E (2020) Letter: Covid-19, and vitamin D. Aliment Pharmacol Ther 51:993-999. https://doi.org/10.1111/apt.15752

Parekh D, Dancer RC, Scott A et al (2018) Vitamin D to prevent lung injury following esophagectomy - a randomized, placebocontrolled trial. Crit Care Med 46(12):e1128

Peterson CA, Heffernan ME (2008) Serum tumor necrosis factor-alpha concentrations are negatively correlated with serum $25(\mathrm{OH}) \mathrm{D}$ concentrations in healthy women. J Inflamm (Lond) 5:10
Provvedini DM, Tsoukas CD, Deftos LJ, Manolagas SC (1983) 1,25dihydroxyvitamin $\mathrm{d} 3$ receptors in human leukocytes. Science 221: $1181-1183$

Prufer K, Veenstra TD, Jirikowski GF, Kumar R (1999) Distribution of 1, 25-dihydroxyvitamin D3 receptor immunoreactivity in the rat brain and spinal cord. J Chem Immunol 16:135-145

Schleithoff SS, Zittermann A, Tenderich G, Berthold HK, Stehle P, Koerfer R (2006) Vitamin D supplementation improves cytokine profiles in patients with congestive heart failure: a double-blind, randomized, placebo-controlled trial. Am J Clin Nutr 83:754-759

Society AT, I.D.S.o. America (2005) Guidelines for the management of adults with hospital-acquired, ventilator-associated, and healthcareassociated pneumonia. Am J Respir Crit Care Med 171:388-416

Sodhi CP, Wohlford-Lenane C, Yamaguchi Y, Prindle T, Fulton WB, Wang S, McCray PB Jr, Chappell M, Hackam DJ, Jia H (2018) Attenuation of pulmonary ACE2 activity impairs inactivation of des-Arg9 bradykinin/BKB1R axis and facilitates LPS-induced neutrophil infiltration. Am J Physiol-Lung Cell Mol Physiol 314(1): L17-L31

Talmor Y, Bernheim J, Klein O, Green J, Rashid G (2008) Calcitriol blunts pro-atherosclerotic parameters through NFkappaB and p38 in vitro. Eur J Clin Invest 38:548-554

Tikellis C, Thomas MC (2012) Angiotensin-converting enzyme 2 (ACE2) is a key modulator of the renin angiotensin system in health and disease. Int J Peptid 2012:256294

Tsoukas CD, Provvedini DM, Manolagas SC (1984) 1,25dihydroxyvitamin $\mathrm{d} 3$ : a novel immunoregulatory hormone. Science 224:1438-1440

Xu J, Yang J, Chen J, Luo Q, Zhang Q, Zhang H (2017) Vitamin D alleviates lipopolysaccharide induced acute lung injury via regulation of the renin angiotensin system. Mol Med Rep 16(5):74327438

Xu H, Zhong L, Deng J et al (2020) High expression of ACE2 receptor of 2019-nCoV on the epithelial cells of oral mucosa. Int J Oral Sci 12(1):1-5

Xudong X, Junzhu C, Xingxiang W, Furong Z, Yanrong L (2006) Ageand gender-related difference of ACE2 expression in rat lung. Life Sci 78(19):2166-2171

Ye M, Wysocki J, Naaz P, Salabat MR, LaPointe MS, Batlle D (2004) Increased ACE 2 and decreased ACE protein in renal tubules from diabetic mice: a renoprotective combination? Hypertension 43: $1120-1125$

Zou X, Chen K, Zou J, Han P, Hao J, Han Z (2020) Single-cell RNA-seq data analysis on the receptor ACE2 expression reveals the potential risk of different human organs vulnerable to $2019-\mathrm{nCoV}$ infection. Front Med 1-8

Publisher's note Springer Nature remains neutral with regard to jurisdictional claims in published maps and institutional affiliations. 